\title{
Efficiency and productivity analysis for intermediary institutions: Turkish capital markets case
}

Productivity analysis for intermediary institutions

\author{
Guler Aras
}

Department of Business Administration, Center for Finance, Governance and Sustainability (CFGS), Yildiz Technical University, Istanbul, Turkey Yasemin Karaman

Department of Business Administration, Yildz Technical University, Istanbul, Turkey, and

Evrim Hacioglu Kazak

Department of Business Administration, Center for Finance, Governance and Sustainability (CFGS), Yildiz Technical University, Istanbul, Turkey

\begin{abstract}
Purpose - The purpose of this study is to investigate efficiency and productivity of Turkey's both brokerage sector and intermediary institutions (IIs) that have been active in Turkish capital markets.

Design/methodology/approach - Data envelopment analysis (DEA) and Malmquist total factor productivity index (MPI) are used to analyze efficiency and productivity of Turkey's both brokerage sector and 51 Turkish IIs constantly operated between the years 2008 and 2018. Paid-in capital, administrative expenses and trading volumes are used as input, while net trading commissions and net profit/loss are used as output in analysis. The calculations of this analysis are made with DEAP 2.2 program and Python.

Findings - The results reveal that during the analysis period, percentage of efficient institutions among 51 IIs was between $18 \%$ and $39 \%$ while the sector's mean efficiency score ranged between $52 \%$ and $65 \%$. While 2009 is the year with the highest number of efficient institutions, 2013 is observed to be the least. Finally, the results of productivity analysis indicate that all types of IIs are not fully productive during the related period. The striking finding obtained is that though there is a decrease in total productivity change, the technological change has a positive effect on their productivity change.

Originality/value - This study is a double-layered research paper that includes efficiency analysis by DEA in the first step and productivity analysis by using MPI in the second step.
\end{abstract}

Keywords Efficiency, Capital markets, Productivity, Data envelopment analysis, Intermediary institutions, Malmquist total factor productivity index

Paper type Research paper

\section{Introduction}

Intermediary institutions (IIs) are one of the most significant institutions holding a key role in the financial system and Borsa Istanbul (BIST), which is Turkish stock exchange and a developing capital market. According to Turkish Capital Markets Association (TCMA) (2018) annual review report, BIST was ranked 52nd and 22nd in the world with a market value of 795 billion TL (149 billion USD) and a daily trading volume of 8 billion TL (1.7 billion USD),

(C) Guler Aras, Yasemin Karaman and Evrim Hacioglu Kazak. Published in Journal of Capital Markets Studies. Published by Emerald Publishing Limited. This article is published under the Creative Commons Attribution (CC BY 4.0) license. Anyone may reproduce, distribute, translate and create derivative works of this article (for both commercial and non-commercial purposes), subject to full attribution to the original publication and authors. The full terms of this license may be seen at http:// creativecommons.org/licences/by/4.0/legalcode

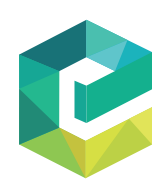

Journal of Capital Markets Studies Vol. 4 No. 2,2020 pp. $193-208$ Emerald Publishing Limited 
JCMS

4,2

194

respectively, as of 2018. Additionally, in terms of number of listed companies, BIST with 376 listed companies was ranked 26th in the world in 2018. Moreover, as seen in Table 1, in terms of market value, BIST was ranked 33rd among the world stock exchanges in 2018.

Capital Markets Board of Turkey (CMB) has classified the IIs pursuant to their authority, responsibility and minimum equity as "Broadly authorized," "Partially authorized" and "Narrowly authorized." "Communiqué on Principles of Establishment and Activities of Investment Firms" (Iii-39.1) that was published in the official gazette edition 28,854 on December 12, 2013, has described this classification in Article 4 as below:

(1) Broadly authorized II: An intermediary institution engaging in any or all of dealing on own account, general custody and/or underwriting-related services and activities;

(2) Partially authorized II: An intermediary institution engaging in any or all of execution of orders, best effort, limited custody and portfolio management-related services and activities;

(3) Narrowly authorized II: An intermediary institution engaging in any or all of reception and transmission of orders and/or investment advice-related services and activities.

With the "Communique on Principles Regarding the Capital and Capital Adequacy of the Intermediary Institutions" (Communiqué Serial: V, No: 34), the minimum equity amounts that the brokerage houses must have are specified. This amount is updated by the CMB every year. As of 2018, pursuant to their license type minimum capital requirements of IIs are 26.209.815 TL for broadly authorized, 10.483.926 TL for partially authorized and 2.096.785 TL for narrowly authorized.

In developed countries including the USA and EU countries, proportion of IIs in financial system is greater than developing countries. In Turkey, this proportion of IIs is $1 \%$, which shows that it is still an emerging sector which makes it more noteworthy to investigate (The Banks Association of Turkey (BAT), 2019) (see Table 2).

The number of IIs operating in Turkey during the analysis period is shown in Figure 1. The decrease in the number of IIs over the years is clearly seen in this graph. By the end of

\begin{tabular}{|c|c|c|c|c|c|}
\hline Ranking & Index & Country & $\begin{array}{l}\text { Market value } \\
\text { (billion dollars) }\end{array}$ & $\begin{array}{l}\text { Market value } \\
\text { share } \%\end{array}$ & $\begin{array}{l}\text { Market value } \\
\quad \text { / GDP } \%\end{array}$ \\
\hline 1 & $\begin{array}{l}\text { New York Stock } \\
\text { Exchange }\end{array}$ & USA & 20,679 & 27.8 & 100.9 \\
\hline 2 & Nasdaq OMX & USA & 9,757 & 13.1 & 47.6 \\
\hline 3 & $\begin{array}{l}\text { Japan Stock } \\
\text { Exchange }\end{array}$ & Japan & 5,297 & 7.1 & 106.5 \\
\hline 4 & $\begin{array}{l}\text { Shanghai Stock } \\
\text { Exchange }\end{array}$ & China & 3,919 & 5.3 & 29.2 \\
\hline 5 & $\begin{array}{l}\text { Hong Kong Stock } \\
\text { Exchange }\end{array}$ & Hong Kong & 3,819 & 5.1 & 1052.0 \\
\hline 6 & $\begin{array}{l}\text { NYSE Euronext } \\
\text { (Europe) }\end{array}$ & $\begin{array}{l}\text { Netherlands, Belgium, } \\
\text { France, Portugal }\end{array}$ & 3,73 & 5.0 & 83.6 \\
\hline 7 & London Group & England, Italy & 3,638 & 4.9 & 74.2 \\
\hline 8 & $\begin{array}{l}\text { Shenzhen Stock } \\
\text { Exchange }\end{array}$ & China & 2,405 & 3.2 & 17.9 \\
\hline 9 & $\begin{array}{l}\text { Bombay Stock } \\
\text { Exchange }\end{array}$ & India & 2,083 & 2.8 & 76.7 \\
\hline 10 & TMX Group & Canada & 1,938 & 2.6 & 113.2 \\
\hline 33 & Borsa Istanbul & Turkey & 149 & 0.2 & 19.5 \\
\hline
\end{tabular}

Table 1.

Market values of stock 10 exchanges-2018 


\begin{tabular}{lcrr}
\hline Sector & Amount & Share in total (\%) & $\begin{array}{r}\text { Productivity } \\
\text { analysis for }\end{array}$ \\
Banks & 3,867 & 83 & $\begin{array}{r}\text { intermediary } \\
\text { institutions }\end{array}$ \\
Portfolio management companies & 167 & 4 & \\
Insurance companies & 171 & 4 & \\
Unemployment insurance fund & 127 & 3 & $\mathbf{1 9 5}$ \\
Pension investment trusts & 91 & 2 & \\
Real estate investment trusts & 77 & 1 & \\
Financial leasing companies & 69 & 1 & Table 2. \\
Factoring companies & 35 & 1 & 1 \\
Finance companies & 40 & 0 & Asset size of financial \\
Intermediary institutions & 55 & 0 & institutions in Turkey \\
Reassurance companies & 1 & 0 & (December 2018, \\
Venture capital funds* & 0.5 & 100 & billion TL) \\
Securities investment trusts & 4,674 & & \\
Total & &
\end{tabular}

2018, 63 IIs were operating in Turkish capital markets of which 22 were bank-originated and 41 were non-bank-originated (Turkish Capital Markets Association (TCMA), 2019).

Despite the decreasing trend in the number of brokerage houses, it is observed that the number of issue investors in BIST has increased over the years and has reached 1.178.919 in 2018. Detailed information including the breakdown of domestic and foreign investors is given in Figure 2.

Figure 3 gives the percentage of the investor concealment balance in BIST between 2008 and 2018 according to domestic and foreign breakdown. While domestic investors come into prominence in terms of the number of accounts, the weight of foreign investors is remarkable regarding balance.

In the light of the above information, it can be clearly stated that the Turkish capital market is in a developing trend. Since the efficient and well-productive IIs carry this market further and support the development of the economic growth, the efficiency and productivity analysis play a crucial role in order to determine the improvement areas of IIs and generate a roadmap for the sector. Accordingly, in this paper, at first, the studies in the literature on efficiency and productivity analysis for IIs are systematically reviewed and provided in the following section. The data set and methodology as well as the research findings are presented in the third section. Finally, in the fourth section, implications and policy suggestions as well as the conclusion of the study are provided.

\section{Literature review}

Despite its important role in the economy, as in other countries, in Turkey, while many efficiency and productivity analysis focus on banks, there are only a few that analyze investigate the efficiency and productivity of IIs.

Fukuyama and Weber (1999), Wang et al. (2003) and Zhang et al. (2006) analyzed the efficiency of brokerage houses in Japan, Taiwan and the USA, respectively, and found that similarly large-scale firms are more efficient than small-scale intermediaries. Contrary to above studies, Gunduz et al. (2001) examined the financial performance of Turkish IIs between 1997 and 1998 by using data envelopment analysis (DEA) and found no significant relation between the efficiency and firm scale. Pursuant to Hu and Fang (2010), firms with larger market shares had higher efficiency scores than the firms with small market share in Taiwan. Beccalli (2004) examined the efficiency of the British and Italian brokerage houses and found that the UK firms were more efficient than the Italian firms and also that the domestic firms were more efficient than foreign firms. According to the study of Bayyurt and Akin (2014), foreign acquisition had positive significant effect on the efficiency of IIs in 
JCMS

4,2

196

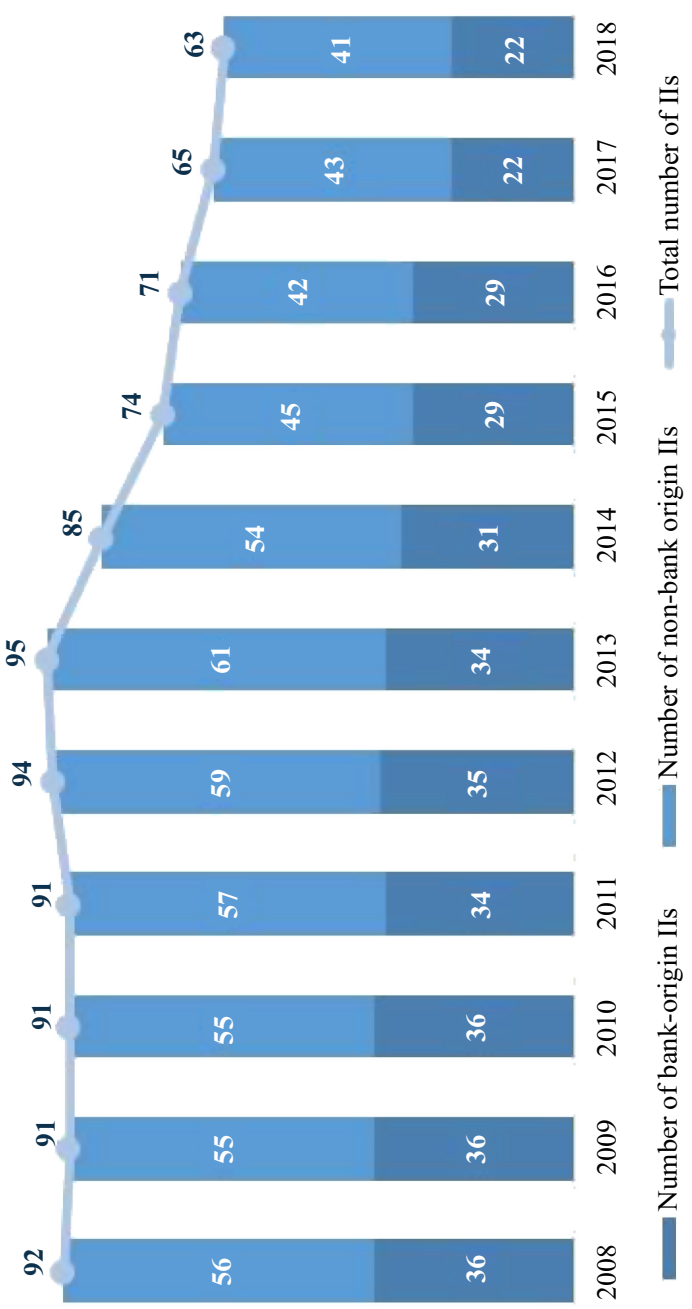

SII Јo .əəqun N

Figure 1.

Number of IIs

operating in Turkish

capital markets

(2008-20018) 


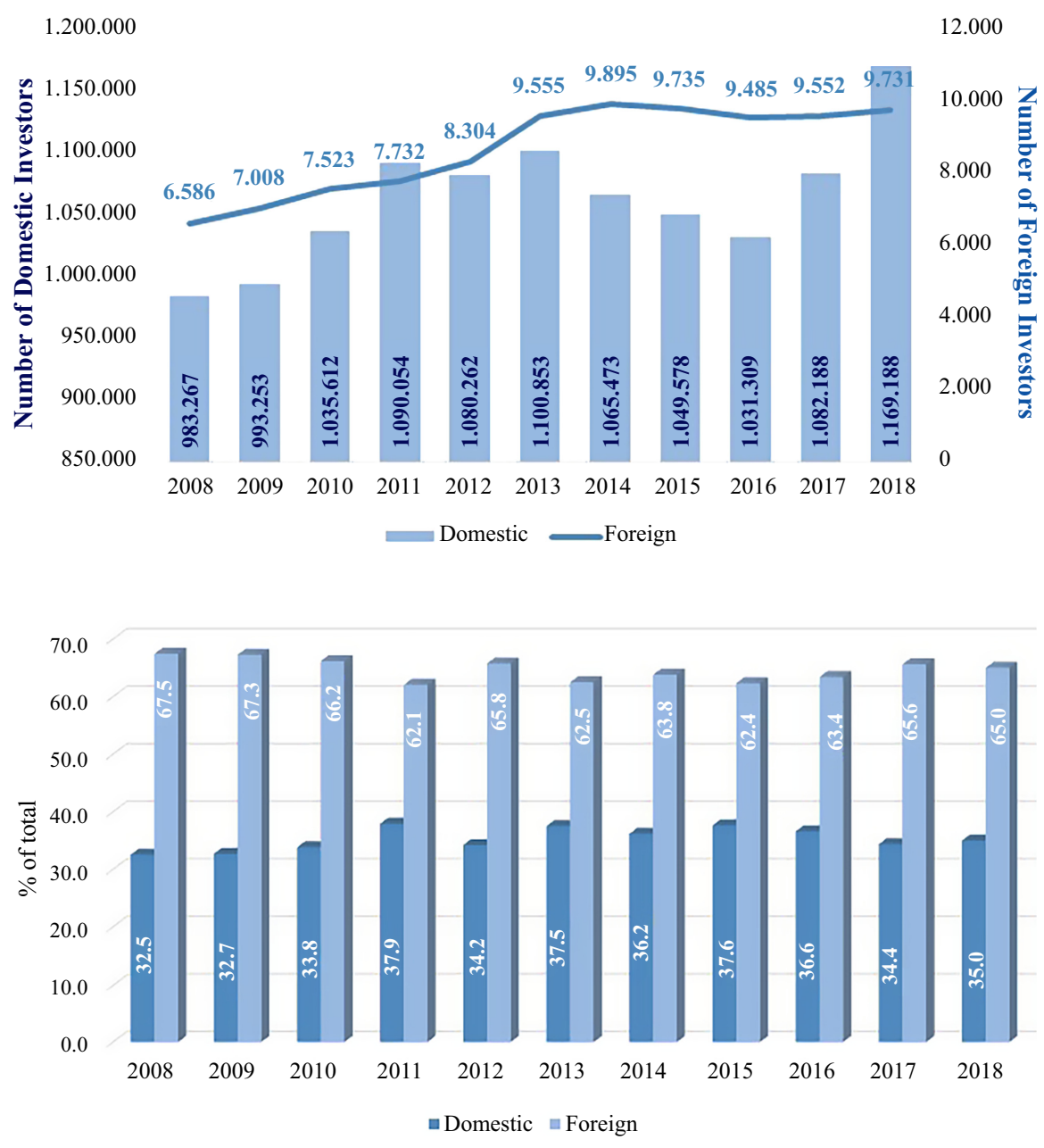

Productivity analysis for intermediary institutions 197

Figure 2. Number of issue investor in BIST (2008-20018)

Figure 3. Investors concealment balance ( $\%$ of total) (2008-2018)

Turkey, and Kadioglu and Gunalp (2019) examined the efficiency of 112 IIs between 2008 and 2015 and found that the efficiency of intermediaries did not affect profitability but market share was found to be one of the major predictive factor of profitability. Aygoren and Yesilyurt (2011) researched the efficiency of Turkish security firms between 2005 and 2008 by using stochastic frontier analysis (SFA) and found that security firm age and labor numbers had positive effect on efficiency, whereas branch numbers, firm size, financial leverage and service ratio had negative effect on the efficiency.

The striking finding in current studies about the efficiency of IIs in the literature, such as Aktas and Kargin (2007), Bagdadioglu et al. (2012), Bayram (2016), Taş and Çevikcan (2017) and Aras et al. (2018b), is that bank-based intermediaries were found to be more efficient than non-bank based intermediaries. Aras et al. (2018a) examined the efficiency and productivity of IIs between 2005 and 2016 in terms of listed and non-listed institutions, and they found that listed institutions were more efficient than non-listed institutions and that the total productivity change of listed IIs was steadier than the non-listed IIs.

The inputs and outputs used mentioned studies in the literature are given in Table 3. 
JCMS

4,2

\begin{tabular}{|c|c|c|c|c|c|c|}
\hline \multirow{2}{*}{$\frac{\text { Year }}{1999}$} & \multirow{2}{*}{$\begin{array}{l}\text { Author/s } \\
\text { Fukuyama and } \\
\text { Weber }\end{array}$} & \multirow{2}{*}{$\frac{\text { Region }}{\text { Japan }}$} & \multicolumn{2}{|c|}{ Input } & \multicolumn{2}{|c|}{ Output } \\
\hline & & & $\begin{array}{l}(1) \\
(2) \\
(3)\end{array}$ & $\begin{array}{l}\text { Labor (number) } \\
\text { Total assets } \\
\text { Capital }\end{array}$ & $\begin{array}{l}(1) \\
(2)\end{array}$ & $\begin{array}{l}\text { Trading commissions } \\
\text { Underwriting revenue }\end{array}$ \\
\hline 2001 & Gunduz et al. & Turkey & $\begin{array}{l}(1) \\
(2) \\
(3)\end{array}$ & $\begin{array}{l}\text { Capital } \\
\text { Administrative expenses } \\
\text { Total assets }\end{array}$ & (1) & Trading commissions \\
\hline 2003 & Wang et al. & Taiwan & $\begin{array}{l}(1) \\
(2)\end{array}$ & $\begin{array}{l}\text { Labor (number) } \\
\text { Capital }\end{array}$ & $\begin{array}{l}(1) \\
(2) \\
(3)\end{array}$ & $\begin{array}{l}\text { Trading commissions } \\
\text { Equity trading revenue } \\
\text { Underwriting revenue }\end{array}$ \\
\hline 2004 & Beccalli & $\begin{array}{l}\text { UK and } \\
\text { Italy }\end{array}$ & $\begin{array}{l}(1) \\
(2)\end{array}$ & $\begin{array}{l}\text { Price of labor } \\
\text { Price of physical capital }\end{array}$ & (1) & Earning assets \\
\hline 2005 & Aslantas & Turkey & $\begin{array}{l}(1) \\
(2) \\
(3)\end{array}$ & $\begin{array}{l}\text { Capital } \\
\text { Administrative expenses } \\
\text { Labor (number) }\end{array}$ & $\begin{array}{l}(1) \\
(2)\end{array}$ & $\begin{array}{l}\text { Trading volume } \\
\text { Trading commissions }\end{array}$ \\
\hline 2006 & Zhang et al. & US & & $\begin{array}{l}\text { Labor (compensation) } \\
\text { Capital }\end{array}$ & (1) & Total revenue \\
\hline 2007 & Aktaş and Kargın & Turkey & & $\begin{array}{l}\text { Capital } \\
\text { Operating expenses }\end{array}$ & $\begin{array}{l}(1) \\
(2)\end{array}$ & $\begin{array}{l}\text { Equity trading volume } \\
\text { Trading commissions }\end{array}$ \\
\hline 2010 & Hu and Fung & Taiwan & $\begin{array}{l}(1) \\
(2) \\
(3)\end{array}$ & $\begin{array}{l}\text { Fixed assets } \\
\text { Capital } \\
\text { General expenses }\end{array}$ & (1) & Market share \\
\hline 2011 & $\begin{array}{l}\text { Aygoren and } \\
\text { Yesilyurt }\end{array}$ & Turkey & $\begin{array}{l}(1) \\
(2) \\
(3)\end{array}$ & $\begin{array}{l}\text { Capital } \\
\text { Service expenses } \\
\text { Operating expenses }\end{array}$ & (1) & Total revenue \\
\hline 2012 & Bagdadioglu et al. & Turkey & $\begin{array}{l}(1) \\
(2) \\
(3) \\
(4)\end{array}$ & $\begin{array}{l}\text { Labor (number) } \\
\text { Branch number } \\
\text { Operating expenses } \\
\text { Capital }\end{array}$ & $\begin{array}{l}(1) \\
(2) \\
(3)\end{array}$ & $\begin{array}{l}\text { Equity trading volume } \\
\text { Fixed-income trading } \\
\text { volume } \\
\text { Operating income }\end{array}$ \\
\hline 2014 & Bayyurt and Akın & Turkey & & $\begin{array}{l}\text { Labor (number) } \\
\text { Operating expenses }\end{array}$ & $\begin{array}{l}(1) \\
(2)\end{array}$ & $\begin{array}{l}\text { Trading revenue } \\
\text { Other revenue }\end{array}$ \\
\hline 2016 & Bayram & Turkey & $\begin{array}{l}(1) \\
(2) \\
(3)\end{array}$ & $\begin{array}{l}\text { Capital } \\
\text { Total assets } \\
\text { Labor (number) }\end{array}$ & $\begin{array}{l}(1) \\
(2) \\
(3) \\
(4)\end{array}$ & $\begin{array}{l}\text { Account number } \\
\text { Trading volume } \\
\text { Trading commissions } \\
\text { Net profit/loss }\end{array}$ \\
\hline 2017 & Aktas and Cevikcan & Turkey & $\begin{array}{l}(1) \\
(2)\end{array}$ & $\begin{array}{l}\text { Capital } \\
\text { Labor (number) }\end{array}$ & $\begin{array}{l}(1) \\
(2) \\
(3)\end{array}$ & $\begin{array}{l}\text { Total revenue per } \\
\text { employee } \\
\text { Net income per employee } \\
\text { Return on equity }\end{array}$ \\
\hline 2019 & $\begin{array}{l}\text { Kadioglu and } \\
\text { Gunalp }\end{array}$ & Turkey & $\begin{array}{l}(1) \\
(2) \\
(3)\end{array}$ & $\begin{array}{l}\text { Price of labor } \\
\text { Price of capital } \\
\text { Price of financial } \\
\text { payables }\end{array}$ & (1) & Total trading volume \\
\hline 2019 & Celik & Turkey & $\begin{array}{l}(1) \\
(2) \\
(3)\end{array}$ & $\begin{array}{l}\text { Administrative expenses } \\
\text { Marketing and sales } \\
\text { expenses } \\
\text { Trade payables }\end{array}$ & $\begin{array}{l}(1) \\
(2) \\
(3)\end{array}$ & $\begin{array}{l}\text { Sales revenue } \\
\text { Interest revenue } \\
\text { Other revenue }\end{array}$ \\
\hline 2019 & Aras et al. & Turkey & $\begin{array}{l}(1) \\
(2) \\
(3) \\
(4)\end{array}$ & $\begin{array}{l}\text { Capital } \\
\text { Labor (number) } \\
\text { Branch number } \\
\text { Operating expenses }\end{array}$ & $\begin{array}{l}(1) \\
(2)\end{array}$ & $\begin{array}{l}\text { Total transaction } \\
\text { volume } \\
\text { Operating income }\end{array}$ \\
\hline
\end{tabular}

The frequency of inputs and outputs used in the efficiency analysis of IIs is as follows (Figure 4):

This research analysis with a double-layered technique by employing efficiency analysis and productivity analysis will contribute to the literature. 


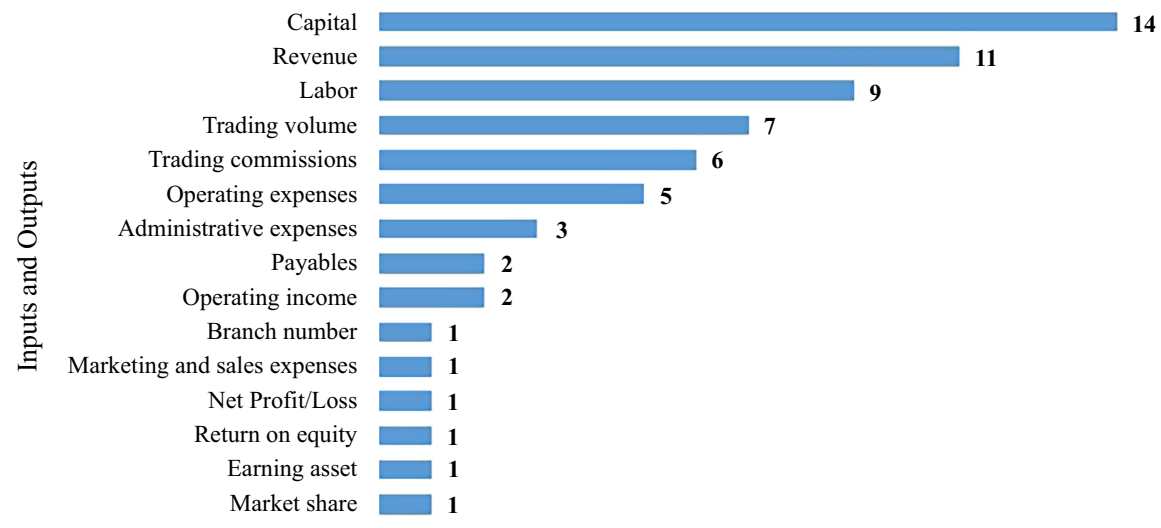

- Frequency
Productivity analysis for intermediary institutions

199

Figure 4. Frequency of inputs and outputs used in the efficiency analysis of

IIs in previous literatüre

\section{Research methodology and data}

\subsection{Data, sample and analysis process}

The major purpose of this two-layer research to evaluate the efficiency and productivity of IIs in Turkey between 2008 and 2018 by using DEA in the first stage and Malmquist total factor index (MPI) in the second stage. The sample consists of both, companies operating between these years and companies operating continuously during the research period. Hereby, this distinction provides a clearer view of the efficiency and productivity of both the sector and the institutions operating continuously in the Turkish capital market. The number of IIs was 97 in 2008 and 63 in 2018, while 51 IIs were constantly operated during the research period from 2008 to 2018. There were 18 broadly authorized, 21 bank-origin broadly authorized, 8 partially authorized, 1 bank-origin partially authorized and 3 narrowly authorized IIs among these 51 IIs.

Inputs and outputs employed in analysis are determined by literature review. Therefore, paid-in capital, administrative expenses and trading volumes (included equity, warrants, fixed income and repo-reverse, fixed income, repo-reverse repo, futures, options and leveraged forex trading volumes) are employed as input, while net trading commissions and net profit/loss are employed as output in this analysis. The financial data of brokerage houses used in the analysis were provided from Turkish Capital Markets Association (TCMA).

Two-layer analysis process in this study is as below:

In the first stage:

(1) 1st Step: The efficiency of all IIs is analyzed on a yearly basis by the CCR-DEA model that is based on input-oriented and constant return to scale. Hereby, the average efficiency scores of the sector is found for each year.

(2) 2nd Step: Average efficiency score of 51 brokerage houses operating constantly during the research period is calculated on a yearly basis.

(3) 3rd Step: In order to compare IIs' efficiency according to their scope of authority and origin, firstly, IIs are divided into three categories as broadly authorized, partially authorized and narrowly authorized, and then each is separated category and divided into two categories as bank origin and non-bank origin. Thus, the average efficiency scores of the all type of intermediaries are found for each year by using the findings obtained in the second step. Golany and Roll (1989) set up a rule stating the number of 
JCMS

4,2

decision-making units (DMUs) should be at least twice the specified number of inputs and outputs, while Bowlin (1998) argues that the number of DMUs should be three times the specified number of inputs and outputs. In line with these rules, DEA could not be applied separately for each category in this study.

In the second stage:

(1) The productivity change analysis of 51 brokerage houses operating constantly between the research period is calculated on a yearly basis by using the MPI.

(2) Assessment the productivity levels of intermediaries in terms of their categories.

\subsection{Methods}

3.2.1 Data envelopment analysis (DEA). In this study, the efficiency of the IIs has been calculated by DEA. DEA, developed by Charnes et al. (1978), is based on Farrell's notion of efficiency. The purpose of DEA is to measure the relative efficiency of homogeneous decision units that produce similar outputs with similar inputs, and thus, this method shows the process to be followed by managers in order to increase the efficiency of inefficient DMUs (Charnes et al., 1994). The main efficiency criterion in DEA is the division of the weighted sums of outputs by the weighted totals of the inputs. Efficiency score must be between 0 and 1 , and the efficiency of DMU increases as it approaches to 1 and decreases as it approaches to 0 .

DEA model with input-oriented approach that is employed in this research aims at the minimum input required to reach the targeted output level. This model is shown mathematically:

$$
\max z=\sum_{r=1}^{s} u_{r} y_{r o}
$$

Restrictions

$$
\begin{gathered}
\sum_{r=1}^{s} u_{r} y_{r j}-\sum_{j=1}^{m} v_{i} x_{i j} \leq 0 \\
\sum_{j=1}^{m} v_{i} x_{i o}=1 \\
v_{i}, y_{r} \geq 0 \quad j=1,2,3 \ldots, n
\end{gathered}
$$

where $x_{i j}$ is the amount of $i$ th output of $\mathrm{DMU}_{j}, y_{r j}$ is the amount of $r$ th input of $\mathrm{DMU}_{j} v_{i}$ is the weights of $i$ th output, $u_{r}$ is the weights of $r$ th input, $m$ is the number of inputs and $s$ is the number of outputs.

3.2.2 Malmquist productivity index (MPI). Malmquist productivity index (MPI) got its name from Sten Malmquist (1953), who first came up with the idea of creating an index with the aid of distance function. It calculates the productivity changes between two given periods into technical efficiency change $(E)$ and technological change $(P)$. If the scores of the Malmquist index or any of its constituent is less than 1, it indicates regress in productivity between $t$ and $t+1$, whereas score greater than 1 indicates progress in the productivity between $t$ and $t+1$. MPI is expressed as below (Färe $e t$ al., 1994):

$$
M_{I}^{t+1}\left(y^{t+1}, x^{t+1}, y^{t}, x^{t}\right)=\left[\frac{D_{I}^{t}\left(y^{t+1}, x^{t+1}\right)}{D_{I}^{t}\left(y^{t}, x^{t}\right)} \times \frac{D_{I}^{t+1}\left(y^{t+1}, x^{t+1}\right)}{D_{I}^{t+1}\left(y^{t}, x^{t}\right)}\right]^{1 / 2}
$$


where $x$ and $y$ are inputs and outputs, respectively. $M$ is MPI, and $I$ indicates an inputorientation. This formula can be converted as follows:

$$
M_{I}^{t+1}\left(y^{t+1}, x^{t+1}, y^{t}, x^{t}\right)=\frac{D_{I}^{t+1}\left(y^{t+1}, x^{t+1}\right)}{D_{I}^{t}\left(y^{t}, x^{t}\right)}\left[\frac{D_{I}^{t}\left(y^{t+1}, x^{t+1}\right)}{D_{I}^{t+1}\left(y^{t+1}, x^{t+1}\right)} \times \frac{D_{I}^{t}\left(y^{t}, x^{t}\right)}{D_{I}^{t+1}\left(y^{t}, x^{t}\right)}\right]^{1 / 2}
$$

Technical efficiency change $(E)$ and technological change $(P)$ are expressed as below:

$$
\begin{gathered}
E=\frac{D_{I}^{t+1}\left(y^{t+1}, x^{t+1}\right)}{D_{I}^{t}\left(y^{t}, x^{t}\right)} \\
P=\left[\frac{D_{I}^{t}\left(y^{t+1}, x^{t+1}\right)}{D_{I}^{t+1}\left(y^{t+1}, x^{t+1}\right)} \times \frac{D_{I}^{t}\left(y^{t}, x^{t}\right)}{D_{I}^{t+1}\left(y^{t}, x^{t}\right)}\right]^{1 / 2}
\end{gathered}
$$

\subsection{Empirical results}

As seen in Figure 5, the results reveal that during the analysis period, both the brokerage sector's and 51 IIs' mean efficiency score are less than 1, which means they are not fully efficient, while the mean of 51 IIs' efficiency scores is higher than the brokerage sector. Additionally, while efficiency scores of "bank-origin broadly authorized," "non-bank origin broadly authorized' and 'narrowly authorized" IIs are above the average score of the sector, efficiency scores of "bank origin partially authorized" and "partially authorized" IIs are below the sector average (See also Table A1 and Table A3).

Figure 6 gives institution-based results in detail. According to findings, percentage of efficient institutions among 51 IIs during the related years ranges between $18 \%$ and $39 \%$, while the sector's mean efficiency score ranges between $52 \%$ and $65 \%$ over the entire period. When the mean efficiency values of the periods are analyzed, it is seen that while the year 2009 has been more efficient, the year 2013 has been less efficient compared to other years
Productivity analysis for intermediary institutions

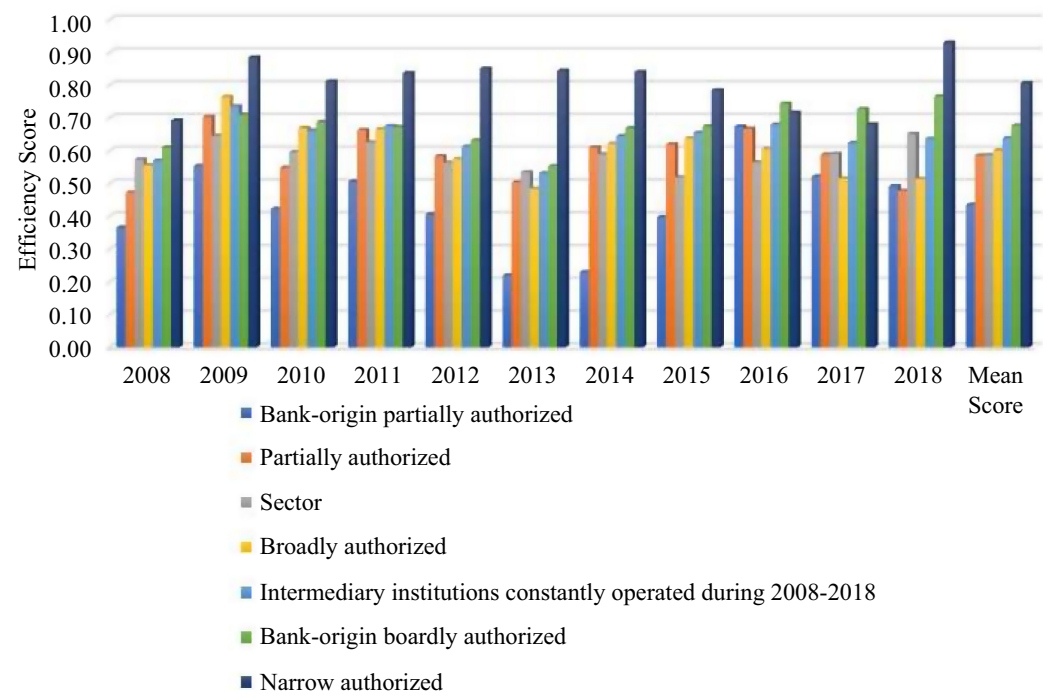

Figure 5. Efficiency scores of IIs 


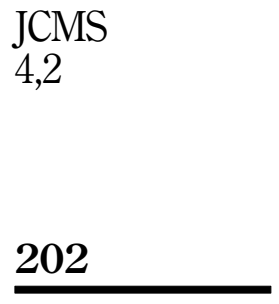

Figure 6.

Number of IIs institution-based efficiency results

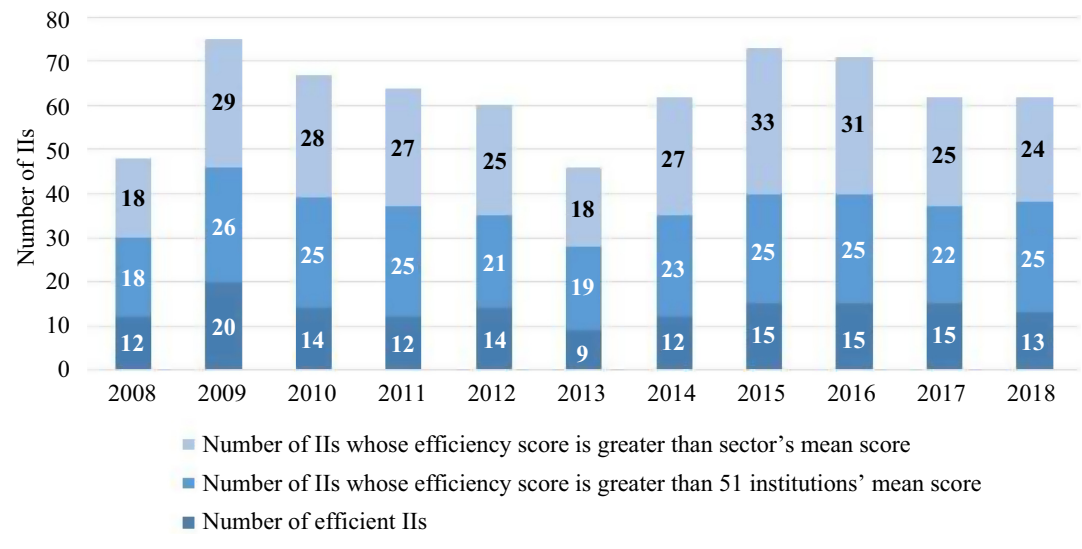

(See also Table A2). In reference to findings, narrowly authorized IIs have been found to be more efficient than the other institutions. Moreover, contrary to current studies stated in the literature, non-bank origin institutions have been found more efficient than bank-origin institutions. It has been thought that this difference has been caused by inputs and outputs used in the research, or the research period.

According to the MPI results that are shown in Figure 7, total factor productivity change (tfpch) of intermediaries that are less than 1 means that intermediaries are not wellproductive. Looking at the components, whereas efficiency change (effch) and scale efficiency change (sech) have affected productivity change (tfpch) negatively and technological change has affected productivity change (tfpch) positively. In line with the DEA results, narrowly authorized IIs are also well-productive than the others, and the most important factor in this result seems to be due to the greater technological progress compared to others.

\section{Conclusion}

IIs are one of the most significant institutions holding a key role in the development of financial system by conducting intermediary activities in line with investor expectations and demands. Thus, the efficient and well-productive IIs carry this market further and support

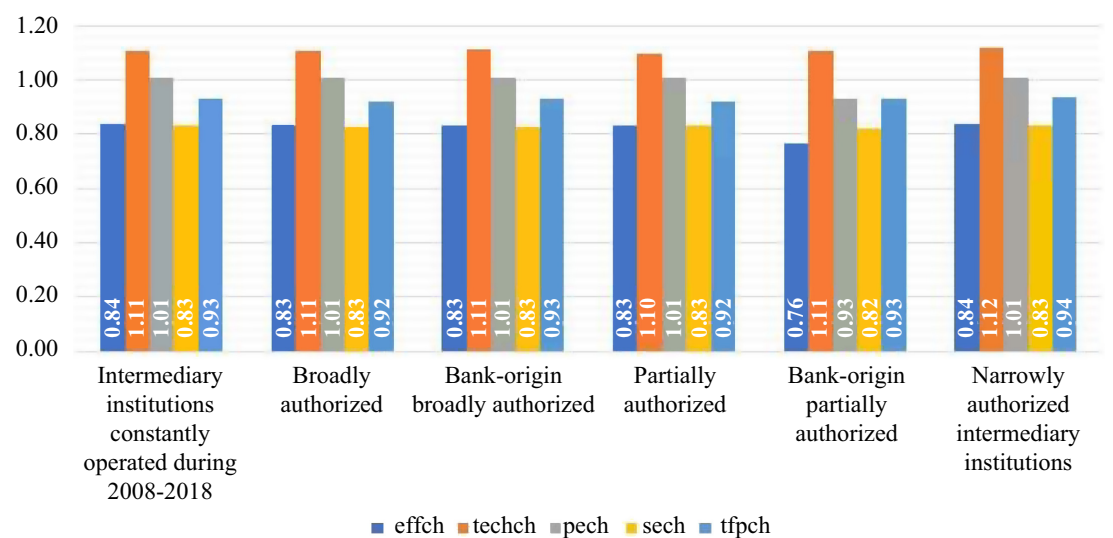

" effch $\equiv$ techch mech $=$ sech $=$ tfpch
Figure 7.

Malmquist index results of intermediary institutions 
the development of the economic growth. Accordingly, the efficiency and productivity analysis have a crucial role in order to determine the improvement areas of IIs and generate a roadmap for the sector.

Aiming to analyze the efficiency and productivity of Turkish IIs between 2008 and 2018 in this study, input-oriented DEA-CCR model is used for efficiency analysis and Malmquist productivity index model is used for productivity analysis. This study contributes to the literature with this double-layered technique by employing efficiency analysis and productivity analysis Additionally, in order to provide more detailed interpretations, IIs' efficiency is evaluated according to their scope of authority and origin. Firstly, IIs are divided into three categories as broadly authorized, partially authorized and narrowly authorized, and then each separate categories is divided into two categories as bank origin and non-bank origin.

Based on DEA and MPI findings, IIs in Turkey have not been found fully efficient and productive during the concerned period. Additionally, findings reveal that narrowly authorized IIs have been found more efficient and more productive than the other groups. Moreover, when compared to bank-origin and non-bank origin brokerage houses, it is seen that non-bank origin brokerage houses have been more efficient than bank-origin brokerage houses. According to Färe et al. (1994), while improvements in the efficiency change represent the proof of catch-up, progress in technological change represents the proof of innovation. Considering this view, the findings of this study give the evidence that IIs in Turkey have attached importance to innovation and have kept up with technological innovation. On the other hand, the findings also reveal that the sector should develop policies toward qualified personnel needs as well as technological innovation.

According to Nishimizu and Page (1982), who referred to all other productivity change as efficiency change, deterioration in efficiency change generally is caused by less technical experience and non-productive management. This reveals that in line with the findings of this study, the progress in management by way of implementing corporate governance principles would provide increase in the efficiency and productivity of Turkish IIs as well. Undoubtedly, it is seen that adopting and implementing corporate governance principles as well as innovation will pave the way for a sustainable growth. Thanks to this sustainable growth, efficient and well-productive institutions will contribute to the development of the economy.

The increasing trend has occurred in a number of issue investors in BIST over the years, while the weightage of foreign investors is remarkable in terms of concealment balance. For supporting the development of a sustainable capital market growth, enhancing the balance between domestic and foreign investors is crucial. Therefore, the policies that can increase the share of domestic investors should be developed. At this point, incentives and financial literacy, and also qualified personnel who will provide qualified investment consultancy, are of great importance.

In conclusion, it is important to take steps in parallel with the findings regarding the current situation for the sustainable development of the intermediary sector. In further studies that include 2019 and 2020 data, it can also be investigated how much Covid-19 pandemic affects the industry.

\section{References}

Aktas, H. and Kargin, M. (2007), "Efficiency and productivity of brokerage houses in Turkish capital market”, Iktisat, Işletme ve Finans, Vol. 22 No. 9, pp. 97-117.

Aras, G., Tezcan, N. and Kutlu Furtuna, O. (2018a), "Does managerial decisions affect efficiency profiles of intermediary institutions? Evidence from emerging economy", The Journal of Operations Research, Statistics, Econometrics and Management Information Systems, Vol. 2 No. 1, pp. 249-262.
Productivity analysis for intermediary institutions 
JCMS

4,2

Aras, G., Tezcan, N., Furtuna, Ö. and Kazak, E. (2018b), Performance and Efficiency Analysis of the Intermediary Institutions in Turkish Capital Markets, Turkish Capital Markets Association, Istanbul.

Aygoren, H. and Yesilyurt, M. (2011), "Impact of firm attributes on the efficiency of brokerage houses”, BDDK Bankactlk ve Finansal Piyasalar, Vol. 5 No. 2, pp. 159-181.

Bagdadioglu, N., Dincer, M. and Yereli, A. (2012), "Efficiency and productivity of the brokerage houses in Turkey", in Çetin, T. and Oğuz, F. (Eds), Regulation and Competiton in the Turkish Banking and Financial Markets, Nova Science Publishers, New York, NY, pp. 201-224.

Bayram, N. (2016), "Data envelopment analysis and total factor productivity: a study on capital market brokerage firms", Verimlilik Dergisi, Vol. 0 No. 2, pp. 7-44.

Bayyurt, N. and Akin, A. (2014), "Effects of foreign acquisitions on the performance of securities firms: evidence from Turkey”, Social and Behavioral Sciences, Vol. 150 No. 2014, pp. 156-161.

Beccalli, E. (2004), "Cross-country comparisons of efficiency: evidence from the UK and Italian investment firms", Journal of Banking and Finance, Vol. 28 No. 6, pp. 1363-1383.

Bowlin, W.F. (1998), "Measuring performance: an introduction to data envelopment analysis (DEA)", The Journal of Cost Analysis, Vol. 15 No. 2, pp. 3-27.

Charnes, A., Cooper, W.W. and Rhodes, E. (1978), "Measuring the efficiency of decision-making units", European Journal of Operational Research, Vol. 2 No. 6, pp. 429-444.

Charnes, A., Cooper, W., Lewin, A. and Seiford, L. (1994), Data Envelopment Analysis Theory, Methodology and Applications, Kluwer Academic Publishers, London.

Färe, R., Grosskopf, S., Norris, M. and Zhang, Z. (1994), "Productivity growth, technical progress, and efficiency change in industrialized countries", American Economic Association, Vol. 84 No. 1, pp. 66-83.

Fukuyama, H. and Weber, W. (1999), "The efficiency and productivity of Japanese securities firms, 1988-1993”, Japan and the World Economy, Vol. 11 No. 1, pp. 115-133.

Golany, B. and Roll, Y. (1989), "An application procedure for data envelopment analysis", Omega, Vol. 1 No. 3, pp. 237-250.

Gunduz, L., Yilmaz, C. and Yilmaz, M. (2001), "The performance analysis of stock brokerage houses in Turkey (1993-1998): a quantitative approach”, Ekonomi ve Yonetim Bilimleri Dergisi, Vol. 1 No. 3, pp. 38-53.

Hu, J. and Fang, C. (2010), "Do market share and efficiency matter for each other? An application of the zero-sum gains data envelopment analysis", Journal of the Operational Research Society, Vol. 61 No. 2010, pp. 647-657.

Kadioglu, E. and Gunalp, B. (2019), "Profitability of brokerage houses in Turkey”, Economic ResearchEkonomska Istraživanja, Vol. 32 No. 1, pp. 1583-1601.

Malmquist, S. (1953), "Index numbers and indifference surfaces”, Trabajos de Estadistica, Vol. 4, pp. 209-242.

Nishimizu, M. and Page, J. (1982), "Total factor productivity growth, technological progress and technical efficiency change: dimensions of productivity change in yugoslavia, 1965-78", The Economic Journal, Vol. 92 No. 368, pp. 920-936.

Tas, O. and Cevikcan, G. (2017), "Efficiency and productivity of Turkish securities firms: 2011-2015", Press Academia, Vol. 3 No. 9, pp. 75-80.

Turkish Capital Markets Association (TCMA) (2018), “Annual review report”, available at: https:// www.tspb.org.tr/wp-content/uploads/2015/08/TCMA-Annual-Review-2018.pdf.

Turkish Capital Markets Association (TCMA) (2019), “Annual review report”, available at: https:// www.tspb.org.tr/wp-content/uploads/2015/08/TCM_2019.pdf.

The Banks Association of Turkey (BAT) (2019), Banks in Turkey 2018, The Banks Association of Turkey, Istanbul. 
Wang, K., Tseng, Y. and Weng, C. (2003), "A study of production efficiencies of integrated securities firms in Taiwan", Applied Financial Economics, Vol. 13 No. 3, pp. 159-167.

Zhang, W.D., Zhang, S. and Luo, X. (2006), "Technological progress, inefficiency, and productivity growth in the US securities industry, 1980-2000", Journal of Business Research, Vol. 59 No. 5, pp. 589-594.
Productivity analysis for intermediary institutions

\section{Further reading}

Celik, I. (2019), "Technical efficiency and determinants of efficiency in Turkish brokerage sector after 2008 globally financial crises: period of 2008-2017", Suleyman Demirel University The Journal of Faculty of Economics and Administrative Sciences, Vol. 24 No. 3, pp. 479-494.

Turkish Capital Markets Association (TCMA) (2020), "Brokerage firms' data”, available at: https:// www.tspb.org.tr/en/data-bank/. 
JCMS

4,2
Appendix

\begin{tabular}{|c|c|c|c|c|c|c|c|c|c|c|c|c|}
\hline No & DMUs & 2008 & 2009 & 2010 & 2011 & 2012 & 2013 & 2014 & 2015 & 2016 & 2017 & 201 \\
\hline 1 & DMU-1 & .27 & 0.61 & 0.27 & 0.38 & 0.11 & 0.33 & 0.61 & 0.53 & 0.78 & 0.43 & \\
\hline 2 & DMU-2 & 43 & .57 & .43 & .61 & 0.46 & 0.42 & 0.22 & 0.31 & 0.51 & .51 & \\
\hline 3 & DMU-3 & 54 & 1.00 & 00 & 00 & 0.99 & 0.46 & 0.89 & 00 & 91 & .00 & \\
\hline 4 & DMU-4 & 0.27 & 0.59 & 0.59 & 0.69 & 0.66 & 0.42 & 0.36 & 0.18 & 0.21 & 0.24 & \\
\hline 5 & DMU-5 & 0.43 & 1.00 & 1.00 & 00 & 1.00 & 1.00 & 1.00 & 0.05 & 0.41 & .07 & \\
\hline 6 & DMU-6 & 0.54 & 0.40 & 0.38 & 7 & 0.60 & 0.37 & 0.49 & 18 & 00 & .00 & \\
\hline 7 & DMU-7 & & 0.34 & & & 0.54 & 0.55 & 0.85 & 0.57 & 51 & 51 & 5 \\
\hline 8 & DMU-8 & 1.00 & 0.71 & 0.24 & 0.27 & 0.28 & 0.17 & 0.22 & 0.28 & 29 & 48 & \\
\hline 9 & DMU-9 & 0.23 & 1.00 & 1.00 & 1.00 & 1.00 & 10 & 1.00 & 1.00 & .00 & .00 & .0 \\
\hline 10 & DMU-10 & 0.28 & 0.65 & & & 1 & 0 & 1 & 1.00 & 00 & .00 & a. \\
\hline 11 & DMU-11 & & & & & & & & & & & \\
\hline 12 & DMU-12 & 1.00 & & 1.00 & & 0.36 & & & & 33 & 16 & .0 \\
\hline 13 & IU-13 & 0.1 & & & & & & 1 & & & & .0 \\
\hline 14 & DMU-14 & & & & & & & & & & & .0 \\
\hline 15 & DMU-15 & & & & & & & & & & & \\
\hline 16 & DMU-16 & 1.0 & & & & & & & & & & \\
\hline 17 & & & & & & & & & & & & .0 \\
\hline 18 & 18 & 0. & & & & & & & & & & \\
\hline 19 & DMU-19 & 0.5 & & & & & & & & & & \\
\hline 20 & & & & & & & & & & & & .5 \\
\hline 21 & 21 & 0.4 & 0.8 & & & & & & & & & \\
\hline 22 & $\mathrm{U}-22$ & & & & & & & & & & & 66 \\
\hline 23 & 3 & & & & & & & & & & & \\
\hline 24 & 4 & 0. & & & & & & & & & & \\
\hline 25 & & & & & & & & & & & & 1 \\
\hline 26 & $\mathrm{~J}-26$ & & & & & & & & & & & 3 \\
\hline 27 & DMU-27 & 0.3 & & & & & & & & & & \\
\hline 28 & & & & & & & & & & & & .0 \\
\hline 29 & 29 & 0. & 0. & & & & & & & & & \\
\hline 30 & & & & & & & & & & & & \\
\hline 31 & $\mathrm{D}$ & & & & & & & & & & & \\
\hline 32 & & & & & & & & & & & & \\
\hline 22 & & & & & & & & & & & & \\
\hline 34 & & 0. & & & & & & & & & & \\
\hline 35 & $\mathrm{D}$ & 0.3 & & & & & & & & & & \\
\hline 2 & & & & & & & & & & & & \\
\hline 37 & & 0. & & & & & & & & & & \\
\hline 38 & & 0.8 & & & & & & & & & & \\
\hline 39 & & & & & & & & & & & & \\
\hline 40 & & 0. & & & & & & & & & & \\
\hline 41 & & 1. & & & & & & & & & & \\
\hline 42 & & 0. & & & & & & & & & & \\
\hline 43 & DMU-43 & 0.8 & & & & & & & & & 22 & \\
\hline 44 & & 0.1 & & & & & & & & & & \\
\hline 45 & & 0. & & & & & & & & & 9 & \\
\hline 46 & DMU-46 & $0.3^{3}$ & & & & & & & & & 28 & \\
\hline 47 & & & & & & & & & & & & \\
\hline 48 & & & & & & & & & & & 3 & \\
\hline 49 & DMU-49 & 0. & & & & & & & & & & \\
\hline 50 & & & & & & & & & & & 0.43 & \\
\hline 51 & DMU-51 & 0.59 & 0.76 & 0.59 & 0.71 & 0.49 & 0.40 & 0.60 & 0.86 & 1.00 & 1.00 & 1.00 \\
\hline
\end{tabular}

Table A1.

Efficiency scores of 51 intermediary institutions constantly operated during the research period

206

206 


\begin{tabular}{|c|c|c|c|c|c|c|c|c|c|c|}
\hline No & DMUs & Research period (\# of year) & Mean & Std & Min & $25 \%$ & $50 \%$ & $75 \%$ & $\operatorname{Max}$ & Productivity \\
\hline 1 & DMU-1 & 11.00 & 0.46 & 0.21 & 0.11 & 0.30 & 0.43 & 0.61 & 0.78 & intermediary \\
\hline 2 & DMU-2 & 11.00 & 0.45 & 0.11 & 0.22 & 0.42 & 0.46 & 0.51 & 0.61 & \\
\hline 3 & DMU-3 & 11.00 & 0.89 & 0.20 & 0.46 & 0.90 & 1.00 & 1.00 & 1.00 & ons \\
\hline 4 & DMU-4 & 11.00 & 0.42 & 0.19 & 0.18 & 0.26 & 0.42 & 0.59 & 0.69 & \\
\hline 5 & DMU-5 & 11.00 & 0.65 & 0.42 & 0.05 & 0.30 & 1.00 & 1.00 & 1.00 & \\
\hline 6 & DMU-6 & 11.00 & 0.58 & 0.29 & 0.18 & 0.39 & 0.49 & 0.80 & 1.00 & 207 \\
\hline 7 & DMU-7 & 11.00 & 0.52 & 0.14 & 0.28 & 0.48 & 0.51 & 0.56 & 0.85 & \\
\hline 8 & DMU-8 & 11.00 & 0.41 & 0.25 & 0.17 & 0.26 & 0.28 & 0.50 & 1.00 & \\
\hline 9 & DMU-9 & 11.00 & 0.93 & 0.23 & 0.23 & 1.00 & 1.00 & 1.00 & 1.00 & \\
\hline 10 & DMU-10 & 11.00 & 0.87 & 0.23 & 0.28 & 0.83 & 1.00 & 1.00 & 1.00 & \\
\hline 11 & DMU-11 & 11.00 & 0.68 & 0.17 & 0.46 & 0.57 & 0.61 & 0.81 & 1.00 & \\
\hline 12 & DMU-12 & 11.00 & 0.66 & 0.34 & 0.16 & 0.35 & 0.61 & 1.00 & 1.00 & \\
\hline 13 & DMU-13 & 11.00 & 0.87 & 0.30 & 0.16 & 1.00 & 1.00 & 1.00 & 1.00 & \\
\hline 14 & DMU-14 & 11.00 & 0.93 & 0.21 & 0.30 & 1.00 & 1.00 & 1.00 & 1.00 & \\
\hline 15 & DMU-15 & 11.00 & 0.49 & 0.22 & 0.26 & 0.31 & 0.43 & 0.59 & 1.00 & \\
\hline 16 & DMU-16 & 11.00 & 0.89 & 0.15 & 0.64 & 0.79 & 1.00 & 1.00 & 1.00 & \\
\hline 17 & DMU-17 & 11.00 & 0.96 & 0.08 & 0.74 & 0.97 & 1.00 & 1.00 & 1.00 & \\
\hline 18 & DMU-18 & 11.00 & 0.74 & 0.23 & 0.29 & 0.61 & 0.75 & 0.93 & 1.00 & \\
\hline 19 & DMU-19 & 11.00 & 0.84 & 0.18 & 0.51 & 0.74 & 0.92 & 1.00 & 1.00 & \\
\hline 20 & DMU-20 & 11.00 & 0.78 & 0.19 & 0.54 & 0.59 & 0.78 & 1.00 & 1.00 & \\
\hline 21 & DMU-21 & 11.00 & 0.50 & 0.12 & 0.38 & 0.43 & 0.45 & 0.55 & 0.80 & \\
\hline 22 & DMU-22 & 11.00 & 0.71 & 0.19 & 0.39 & 0.65 & 0.69 & 0.83 & 0.98 & \\
\hline 23 & DMU-23 & 11.00 & 0.91 & 0.18 & 0.52 & 0.96 & 1.00 & 1.00 & 1.00 & \\
\hline 24 & DMU-24 & 11.00 & 0.60 & 0.16 & 0.38 & 0.50 & 0.57 & 0.68 & 0.91 & \\
\hline 25 & DMU-25 & 11.00 & 0.66 & 0.33 & 0.10 & 0.42 & 0.65 & 1.00 & 1.00 & \\
\hline 26 & DMU-26 & 11.00 & 0.52 & 0.23 & 0.25 & 0.35 & 0.39 & 0.68 & 1.00 & \\
\hline 27 & DMU-27 & 11.00 & 0.43 & 0.14 & 0.22 & 0.38 & 0.42 & 0.51 & 0.67 & \\
\hline 28 & DMU-28 & 11.00 & 1.00 & 0.00 & 1.00 & 1.00 & 1.00 & 1.00 & 1.00 & \\
\hline 29 & DMU-29 & 11.00 & 0.50 & 0.32 & 0.13 & 0.26 & 0.42 & 0.71 & 1.00 & \\
\hline 30 & DMU-30 & 11.00 & 0.74 & 0.22 & 0.39 & 0.58 & 0.82 & 0.93 & 1.00 & \\
\hline 31 & DMU-31 & 11.00 & 0.65 & 0.17 & 0.46 & 0.53 & 0.62 & 0.77 & 1.00 & \\
\hline 32 & DMU-32 & 11.00 & 0.51 & 0.40 & 0.06 & 0.17 & 0.35 & 1.00 & 1.00 & \\
\hline 33 & DMU-33 & 11.00 & 0.43 & 0.22 & 0.11 & 0.24 & 0.53 & 0.60 & 0.69 & \\
\hline 34 & DMU-34 & 11.00 & 0.40 & 0.18 & 0.24 & 0.26 & 0.36 & 0.45 & 0.82 & \\
\hline 35 & DMU-35 & 11.00 & 0.37 & 0.14 & 0.14 & 0.28 & 0.36 & 0.42 & 0.60 & \\
\hline 36 & DMU-36 & 11.00 & 0.52 & 0.23 & 0.15 & 0.37 & 0.46 & 0.67 & 0.87 & \\
\hline 37 & DMU-37 & 11.00 & 0.38 & 0.10 & 0.24 & 0.32 & 0.37 & 0.46 & 0.55 & \\
\hline 38 & DMU-38 & 11.00 & 0.99 & 0.05 & 0.85 & 1.00 & 1.00 & 1.00 & 1.00 & \\
\hline 39 & DMU-39 & 11.00 & 0.50 & 0.27 & 0.04 & 0.39 & 0.52 & 0.60 & 1.00 & \\
\hline 40 & DMU-40 & 11.00 & 0.76 & 0.25 & 0.33 & 0.54 & 0.79 & 1.00 & 1.00 & \\
\hline 41 & DMU-41 & 11.00 & 0.39 & 0.22 & 0.26 & 0.28 & 0.29 & 0.39 & 1.00 & \\
\hline 42 & DMU-42 & 11.00 & 0.37 & 0.24 & 0.16 & 0.23 & 0.33 & 0.39 & 1.00 & \\
\hline 43 & DMU-43 & 11.00 & 0.57 & 0.29 & 0.22 & 0.34 & 0.53 & 0.82 & 1.00 & \\
\hline 44 & DMU-44 & 11.00 & 0.72 & 0.26 & 0.17 & 0.53 & 0.82 & 0.91 & 1.00 & \\
\hline 45 & DMU-45 & 11.00 & 0.53 & 0.17 & 0.29 & 0.47 & 0.52 & 0.59 & 0.88 & \\
\hline 46 & DMU-46 & 11.00 & 0.44 & 0.14 & 0.28 & 0.35 & 0.39 & 0.52 & 0.69 & \\
\hline 47 & DMU-47 & 11.00 & 0.91 & 0.16 & 0.52 & 0.89 & 1.00 & 1.00 & 1.00 & \\
\hline 48 & DMU-48 & 11.00 & 0.43 & 0.17 & 0.21 & 0.32 & 0.35 & 0.54 & 0.75 & \\
\hline 49 & DMU-49 & 11.00 & 0.93 & 0.18 & 0.41 & 1.00 & 1.00 & 1.00 & 1.00 & Table A \\
\hline 50 & DMU-50 & 11.00 & 0.45 & 0.20 & 0.31 & 0.33 & 0.39 & 0.46 & 1.00 & Descriptive statistics of \\
\hline 51 & DMU-51 & 11.00 & 0.73 & 0.22 & 0.40 & 0.59 & 0.71 & 0.93 & 1.00 & DEA resul \\
\hline
\end{tabular}


JCMS

4,2

208

\begin{tabular}{|c|c|c|c|c|c|c|c|c|c|c|c|c|}
\hline DMUs & 2008 & 2009 & 2010 & 2011 & 2012 & 2013 & 2014 & 2015 & 2016 & 2017 & 2018 & $\begin{array}{l}\text { Mean } \\
\text { score }\end{array}$ \\
\hline $\begin{array}{l}\text { Bank-origin } \\
\text { partially } \\
\text { authorized }\end{array}$ & 0.37 & 0.55 & 0.42 & 0.51 & 0.41 & 0.22 & 0.23 & 0.40 & 0.67 & 0.52 & 0.49 & 0.43 \\
\hline $\begin{array}{l}\text { Partially } \\
\text { authorized }\end{array}$ & 0.47 & 0.70 & 0.55 & 0.66 & 0.58 & 0.50 & 0.61 & 0.62 & 0.67 & 0.59 & 0.48 & 0.58 \\
\hline Sector & 0.57 & 0.65 & 0.60 & 0.63 & 0.56 & 0.53 & 0.59 & 0.52 & 0.56 & 0.59 & 0.65 & 0.59 \\
\hline $\begin{array}{l}\text { Broadly } \\
\text { authorized }\end{array}$ & 0.56 & 0.76 & 0.67 & 0.67 & 0.57 & 0.48 & 0.62 & 0.64 & 0.60 & 0.52 & 0.51 & 0.60 \\
\hline $\begin{array}{l}\text { Intermediaries } \\
\text { constantly } \\
\text { operated during } \\
2008-2018\end{array}$ & 0.57 & 0.73 & 0.66 & 0.67 & 0.61 & 0.53 & 0.64 & 0.65 & 0.68 & 0.62 & 0.64 & 0.64 \\
\hline $\begin{array}{l}\text { Bank-origin } \\
\text { broadly } \\
\text { authorized }\end{array}$ & 0.61 & 0.71 & 0.69 & 0.67 & 0.63 & 0.55 & 0.67 & 0.67 & 0.74 & 0.73 & 0.77 & 0.68 \\
\hline $\begin{array}{l}\text { Narrowly } \\
\text { authorized }\end{array}$ & 0.69 & 0.88 & 0.81 & 0.84 & 0.85 & 0.84 & 0.84 & 0.78 & 0.72 & 0.68 & 0.93 & 0.81 \\
\hline
\end{tabular}

\section{Corresponding author}

Yasemin Karaman can be contacted at: gayanekaraman@gmail.com

For instructions on how to order reprints of this article, please visit our website:

www.emeraldgrouppublishing.com/licensing/reprints.htm

Or contact us for further details: permissions@emeraldinsight.com 